\title{
MEASUREMENT OF TWO-PHASE GAS-LIQUID FLOW USING STANDARD AND SLOTTED ORIFICE
}

\author{
Barbara Tomaszewska-Wach ${ }^{1}$,Mariusz Rząsa ${ }^{1}$, Marcin Majer ${ }^{2}$ \\ ${ }^{1}$ Opole University of Technology, Departament of Thermal Engineering and Industrial Facilities, Opole, Poland, ${ }^{2}$ Opole University of Technology, Department of Parallel \\ Systems and Artificial Intelligence, Opole, Poland
}

\begin{abstract}
The differential pressure of gas measurement is very often used in industrial measurements. During the gas flow, liquid condensation often occurs. The result is that when measuring a gas flow, the gas-liquid mixture is essentially measured. Errors in the indications of measuring instruments are starting to appear due to a change in the properties of the continuous phase, which is gas. In addition, the appearance of liquid droplets leads to flow disturbances and pressure pulsations. Therefore, new methods and tools for measuring the flow of gas-liquid mixture are being sought. The work involves the use of slotted orifices for measuring gas-liquid mixtures. An analysis of the influence of the slotted orifice geometry on the measurement of the biphasic mixture stream was carried out. Standard orifice and three slotted orifices of various designs. The experiment included measuring the air flow with a small amount of water dispersed in the form of drops.
\end{abstract}

Keywords: standard orifice, slotted orifice, mixture gas-liquid

\section{POMIAR STRUMIENIA MIESZANINY GAZ-CIECZ Z WYKORZYSTANIEM KRYZY STANDARDOWEJ I KRYZY SZCZELINOWEJ}

Streszczenie. Pomiar gazu metoda zwężkowa jest bardzo często stosowany w pomiarach przemystowych. Podczas przeplywu gazu bardzo często dochodzi do wykroplenia się cieczy. Powoduje to, że mierzac przeplyw gazu w zasadzie mierzy się mieszaninę gaz - ciecz. Zaczynaja pojawiać się błędy wskazań przyrząów pomiarowych wynikających ze zmiany właściwości fazy ciągłej, która jest gaz. Dodatkowo pojawienie się kropel cieczy prowadzi do powstawania zaburzeń przepływu i pulsacji ciśnienia. W zwiazku z tym poszukuje się nowych metod i narzędzi do pomiaru przephywu mieszaniny gaz-ciecz. Praca obejmuje zastosowanie kryz szczelinowych do pomiaru mieszanin gaz-ciecz. Przeprowadzono analize wptywu geometrii kryzy szczelinowej na pomiar strumienia mieszaniny dwufazowej. Badaniom kryze standardowa oraz trzy kryzy szczelinowe o różnych konstrukcjach. Eksperyment obejmowat pomiar przepływu powietrza z niewielka ilościa wody rozproszonej w postaci kropel.

Slowa kluczowe: kryza standardowa, kryza szczelinowa, mieszanina gaz-ciecz

\section{Introduction}

Orifice meters are employed in flow measurements in many branches of industry. When a particular industrial application involves the transport of gas, we often have to do with the conditions when liquids carried with gas are condensed inside a tube. The existence of small liquid droplets leads to the measurement errors resulting from variable physical properties of the flow in the conditions when measurements are performed using orifice meters. Such phenomena occur as a consequence of the loss of the homogeneity of the gas phase flow. In such cases, gas takes the form of a two-phase mixture comprising gas and liquid phases. As a result of using standard methods in the measurements of homogeneous fluids, significant levels of measurement error are encountered. For these reasons, some of the currently challenging problems facing flow metrology are associated with the measurements of two-phase mixtures. The measurements concerned with mass flow rates of gas-liquid mixtures play an important role in many branches of engineering, for example power sector as well as applications in petrochemical and chemical areas [4]. This stems from fact that the occurrence of a dispersed phase results in the variations of the physical parameters of the continuous phase [5].

The approach to measurements outlined above can also be applied in the areas where natural gas is saturated with liquid. Wet gas provides a common example of such flow, i.e. gas in which the liquid phase does not exceed $5 \%$ of the volume fraction [7]. As a result of the economic feasibility of extracting gas from various inaccessible sources, such as mining in sea beds, desert and arctic areas, as well as other remote places, there is a need to develop reliable, small size and low cost metering systems [7, 8]. Another area in which the principle of differential measurement can be employed, includes waste composting [2], where the flows of wet gas occurs. Research has been conducted over the past years in many research centers and scientific institutions with the purpose of improving existing techniques and developing new ones to be applied in the metering of two-phase mixture flows. It is common for such measurements to employ equipment with large dimensions, complex structure and high cost of performance. Therefore, a current challenge facing engineering is associated with the need to design metering equipment with a simple design that can be built and assembled at a low cost. Differential pressure meters provide some of the examples of cheap flow measurement solutions with high performance. AS a result of their simple design, low cost of production, they are suitable for applications in industry. Recent reports include a variety of examples giving the applications of orifice plate meters in the measurement involving mixtures comprising gas and small amounts of liquids $[6,14]$

\section{Measurements of flow mixture by differential pressure flowmeters}

The measurements of the fluid flow rates by application differentia pressure flowmeter consist in the use of a constriction of the flow cross-section. This constriction leads to an increase in the fluid velocity, and along with the change in the velocity, the static pressure decreases and a differential pressure is developed at the orifice. The resulting differential pressure $\Delta \mathrm{P}$ forms a reliable source serving for determination of the fluid mass or volume [5]. Among the orifices meters, we can distinguish: orifice plates, nozzles and Venturi tubes [10]. In this work, various types of orifice meters were applied in experimental research.

\subsection{Standard orifice}

A vast proportion of metering systems apply standard orifices as the simplest and reliable equipment for measuring fluid flow. The standard orifice is also characterized by considerable strength and lack of moving parts. The standard orifice can be successfully applied in measurements involving liquids, gas and suspensions, as they perform measurements well in extreme operating conditions, over a wide range of pressures and temperatures [5]

Differential pressure flowmeters are designed for measuring single-phase fluids, ensuring high measurement accuracy. However, when these types of flow meters are used in wet gas applications, due to the presence of liquids in the flow, the results tend to have a positive bias in the flow measurement. The presence of liquid droplets in the flowing gas results in an increase in the differential pressure $\Delta \mathrm{p}[7,8,14]$. Therefore, we can state a general remark that differential pressure flowmeters indicate an overestimated value of the gas mass flow. The uncorrected gas stream is often called the superficial gas flow. 


\subsection{Special orifice}

The differential pressure flowmeter may be used to measure the gas - liquid droplet flow, however it is necessary to use the appropriate measuring orifice construction. Over the years, many researchers, including Hall, Geng, Morrison, and Kumar, have presented various design solutions that are a modification of the standard orifice, Fig. 1. Such orifices are called special orifices, and you can distinguish, among others, slotted, perforated, fractal or other $[1,3,7-9,11,12]$. In the literature, you can also find orifices with various hole shapes, e.g. square, triangular, oval, longitudinal.

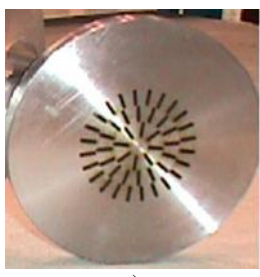

a)

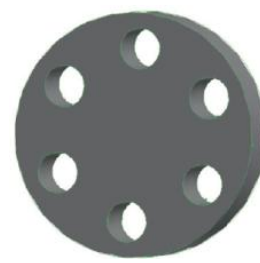

b)

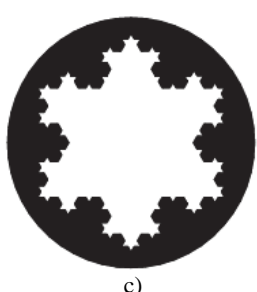

Fig. 1. Examples of special orifices: a) slotted orifice [7, 8], b)perforated orifice $[3,9]$, c) fractal orifice [1]

The reason for wet gas formation is often associated with a decrease in temperature or pressure, and when condensation processes are encountered in the pipeline, this leads to accumulation of small amounts of liquid in the form of droplets that are condensed on the pipeline walls. And it is known that even small amounts of liquid in the flow of gas can lead to flow disturbance.

The Lockhart-Martinelli parameter forms one of the most commonly applied characteristic that can be used to define the relative fraction of liquid in a two-phase flow. It is defined by the formula [6-8]:

$$
X_{L M}=\frac{m_{L}}{m_{G}} \sqrt{\frac{\rho_{G}}{\rho_{L}}}
$$

where: $m_{L}$ and $m_{G}$ are mass flow rates of the liquid and gas phases, respectively, and $\rho_{L}, \rho_{G}$ are the liquid and gas densities. For the wet gas, the value of the $X_{L M}$ parameter does not exceed 0.35.

\section{Experimental setup}

The diagram of the setup applied in the testing the flow of gasliquid mixture is presented in Figure 2. The purpose of the tests was to determine the effect of the slotted orifice geometry on the resulting pressure difference measured for the flow of the gasliquid mixture.

The air into this installation was fed via a compressor. The air was routed for the experiment via a throttling valve, which provided a constant pressure value of 0.5 bar. The flow rate of the air was regulated by a valve. The parameters of the air flow were controlled by a measuring system comprising a pressure sensor and a temperature sensor and an orifice plate. Water was supplied from the water network to a chamber in which the two-phase mixture was formed, and the flow rate was regulated by a valve. The flow rate of the water was measured by a rotameter (VEB MLW Prüfgeräte - Werk) and its measuring rage was equal to $0.2-0.6 \mathrm{~m}^{3} / \mathrm{h}$ ) . The horizontal section of the pipeline comprised a system designed for testing slotted orifice plates that could be removed and replaced. The differential pressure resulting from the installation of the slotted orifice plates was measured with a differential pressure transducer (Aplisens typ PR-50G) and the measuring range was $-10 \mathrm{kPa}-10 \mathrm{kPa}$. The static pressure value in the pipeline was measured with a sensor (TRUCK typ PC001-Gi1/4A1M-U8X-H114), measuring range 0-1 bar. A separator was applied to remove the air from the liquid at the end of the measuring section in the installation. The values of signals from the measurement sensors were recorded continuously by a dedicated card on a PC throughout the duration of the experiment.

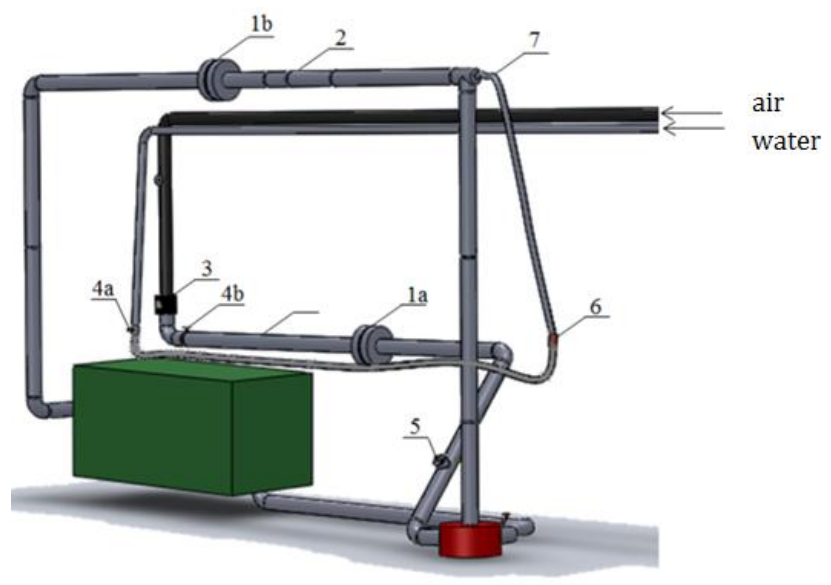

Fig. 2. Diagram of the experimental setup: $1 a, 1 b$-differential pressure meter, 2 - pressure sensor, 3 - reducing valve, $4 a$ - liquid flow regulating valve, $4 b$-air flow regulating valve, 5 -temperature sensor, 6 - rotameter, 7 - water spray nozzle, $a$-air, $w$-water

The measurements were carried out for two mass flow rates of air, which were equal to $216 \mathrm{~kg} / \mathrm{h}$ and $313 \mathrm{~kg} / \mathrm{h}$, respectively. After the gas flow was stabilized, water was fed into the installation in the range of flow rates from $216 \mathrm{~kg} / \mathrm{h}$ to $576 \mathrm{~kg} / \mathrm{h}$.

In experimental research, the orifices were used: standard and three variants of slotted orifices. Diagrams of the orifices used in the experimental studies are shown in the figure 3.

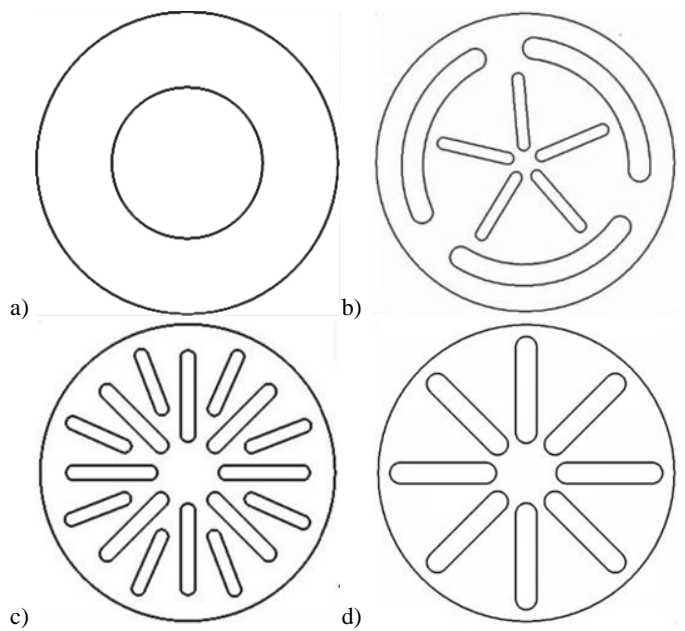

Fig. 3. Orifice plates applied in the experimental research: a) standard orifice, b) slotted orifice 1, c) slotted orifice 2, c) slotted orifice 3

Slotted orifices were designed by the authors of this work. The design of the slots in the slotted orifice is selected in such a way that the mass flow rate can pass through the entire diameter of the pipeline. The slots in slotted orifice 2 and 3 are arranged radially, with the only difference that the geometry of the slots is such that in comparison to orifice no. 2, the slots in orifice no. 3 are wider and longer. The purpose of this geometry was to check which design can offer better flow characteristics. In addition to the slots with radial arrangement, slotted orifice no. 1 has three arc-shaped slots, which are arranged concentrically close to the wall of the pipeline. The dimensions of the slots in the slotted orifices were chosen so that the surface area of these slots was equal to the area of the orifice hole. The orifice ratio of all orifices was the same and was $\beta=0.5$.

The $\beta$ ratio is determined by the formula:

$$
\beta=\sqrt{\frac{A_{\text {slots }}}{A_{\text {pipe }}}}
$$

where: $A_{\text {slots }}$ surface area of the slots, $A_{\text {pipe }}$ - cross-sectional area of the pipe. 


\section{Results of experimental research}

Figure 4 contains the results of the measurements of the differential pressure as a function of the mass fraction of liquid in the constant gas flow rates, for $216 \mathrm{~kg} / \mathrm{h}$ and $313 \mathrm{~kg} / \mathrm{h}$, respectively. The values in terms of the mass fraction of the liquid were determined on the basis of the measurements of gas and liquid flows by application of the following relations:

$$
\alpha=\frac{m_{L}}{m_{L}+m_{G}}
$$

where: $m_{L}$ and $m_{G}$ are mass flow rates of the liquid and gas, respectively.

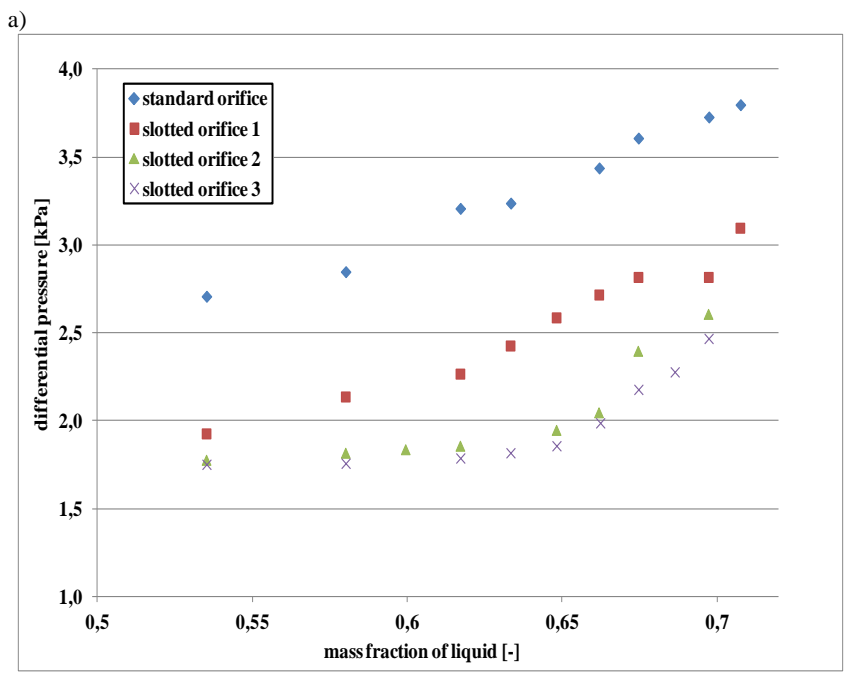

The analysis of the results in Figure 4 demonstrates that the distortions in differential pressure in the orifice due to the presence of the liquid phase in the constant air flow. The value of differential pressure in this case is due to greater fraction of the liquid in the air flow. The distribution of the differential pressure is non-linear. We can note that for the case of slotte dorifice, lower values of differential pressure are generated by the mixture omprising air and water compared to the standard orifice. Thestudy demosntrated that slotted orifice with a radial of slot arrangement has the lowest sensitivity to fluctuations in the mass fractions of the liquids.

b)

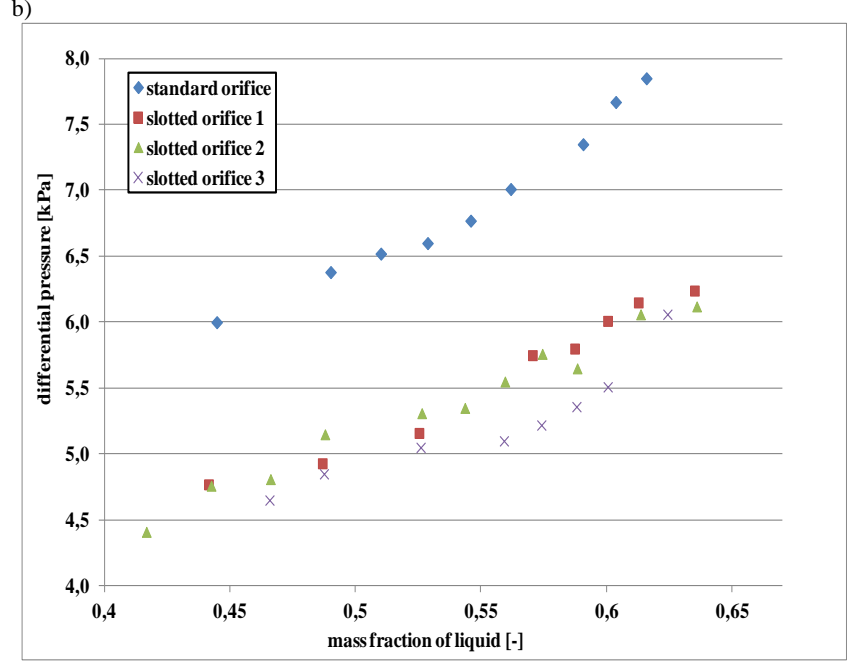

Fig. 4. Dependence between the differential pressures and water mass fraction for the airflow rates equal to: a) $216 \mathrm{~kg} / \mathrm{h}, \mathrm{b}) 313 \mathrm{~kg} / \mathrm{h}$

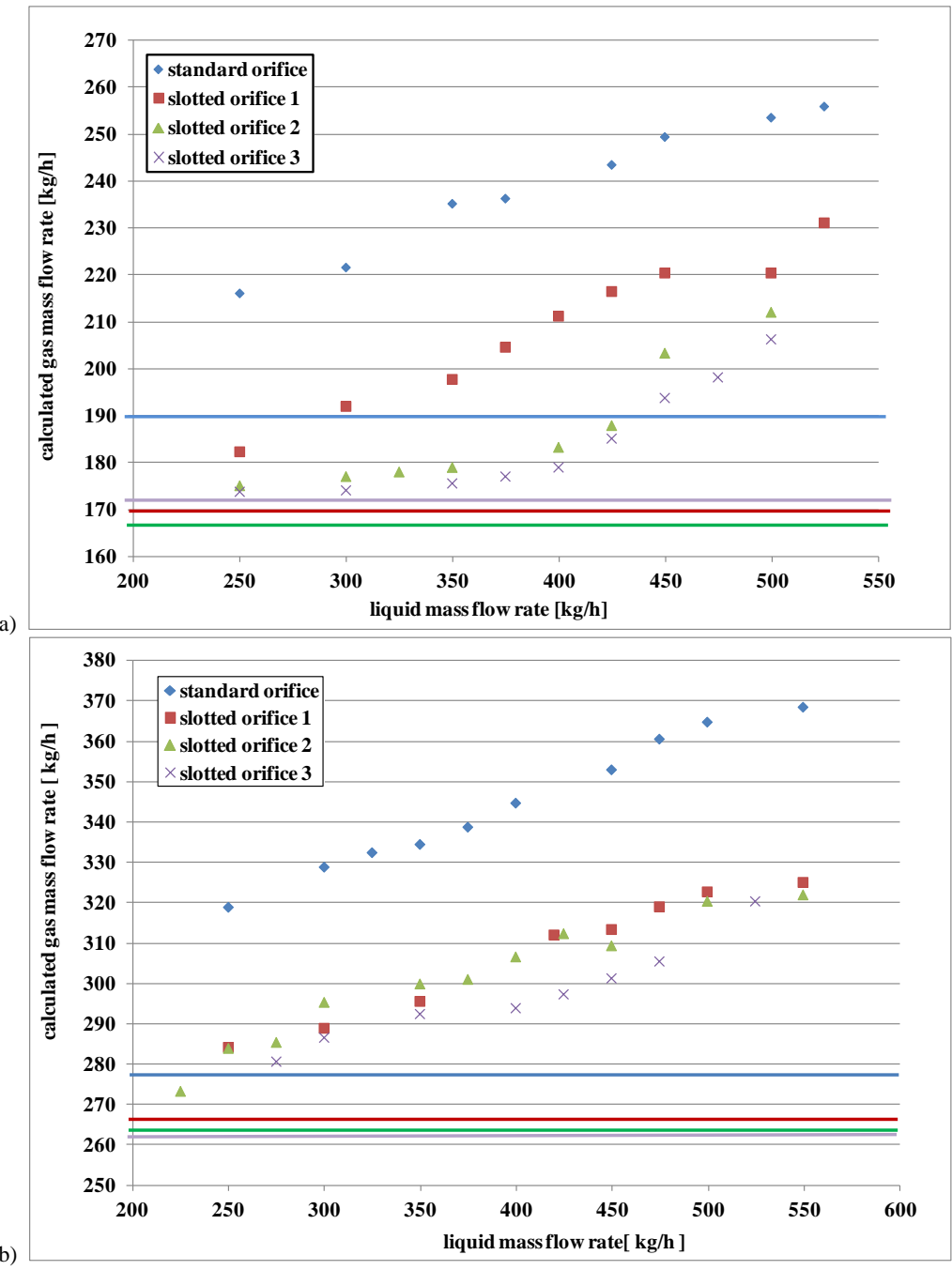


In such conditins, gas comtaining liquid droplets is carried over through the obstacle, and only a small proprtion of the liquid is separated near the orifice. The slots arranged on the crosssection of the pipe result in the entrainment of the liquid along with the gas flow. In a standard orifice, some of the liquid is held up downstream of the orifice, leading to liquid accumulation and additional flow distortions.

The chart in Fig. 5 contains the results of the comparison of the mass flow rate of the gas taking into account the differential pressure during wet gas flow and flow of pure gas.

The results of a comparison between the mass flow rates of gas and one for water that was measured in the investigated orifices plates are presented in a grphical form in Fig. 5. The formula derived from the norm (ISO 5167) formed the basis for the calculation of the mass flow rate of the gas phase to account for the differential pressure that accompnies the gas-liquid flow. The horizontal lines on the diagrams denote the mass flow rates for the case of single-phase gas flow. The blue line marks the mass flow rate of gas for the standard orifice, red refers to the slotted orifice 1 , whereas the green and violet ones relate to the gas mass flow rated measured for the slotted orifices 2 and 3, respectively. We can note that in the chart above marked by a, the green and violet lines follow the same course.

We can remark here that the increase in the flow rate of water leads to the greater value of the error of the meausred gas flow rate. As a result of the application of the standard orifice in the flow of gas-small amount of liquid, the measurments of the flow rate of gas that account for the gas-liquid differential pressure give $18-32 \%$ greater values in comparison to the case of the single-gas flow through the pipeline. For the slotted orifices numbered 1,2 , 3 , the range of this error is $11-30 \%, 10-25 \%$ and $5-23 \%$ respectively.

\section{Conclusions}

The results of the resrafch reported in this paper demonstrate that the surface profiles and the geometric details of the perforations on slotted orifices have an effect on the lnegth of the region needed for the flow to stabilize and affect the value of permanent pressure drop. The process responsible for this is associated with the separation of the mixture into several smaller fluxes. In the case when flow metering applies a slotted orifice, recirculation zone is not normally developed. The use of the common standard orifice forms the reason for the occurrence of flow distortions leading to the generation of energy losses. However, the length of the hydraulic stabilization region in the flow is dependent to a large extent on the design of the slotted orifices and its value takes on smaller value compared to the case of a standard orifice. Moreover, the results of the study have demonstrated that the existence of perforations on the surface of the slotted orifice meters has a positive effect on homogenization of the flow and decrease of pressure pulsations, which form the major sources of the measurement error. Nevertheless, a disadvantage of slotted orifices is associated with the decrease of the differential pressure, loading to a limited sensitivity of flow measurements. This area needs further analysis associated with an attempt to strike a balance between the the above advantages and disadvantages of the use of various slotted orifice designs in particular engineering applications. In this aspect, studies need to be concerned with the determination of the suitable arrangement of slots suitable in specific applications.

\section{References}

[1] Abou El-Azm Aly A., Chong A., Nicolleau F., Beck S.: Experimental study of pressure drop after fractal-shaped orifice in turbulent pipe flow. Experimental Thermal and Fluid Science 34, 2010, 104-111.

[2] Anders D., Rząsa M. R.: The possibility of composting animal waste products Environment Protection Engineering 33(2), 2007, 7-15.

[3] Bayazit Y., Sparrow M., Joseph D.: Perforated plates for liquid management: Plate geometry effects and flow regime. International Journal of Thermal Sciences 85, 2014, 101-111.

[4] Bertani C., De Salve M., Malandrone M., Monni G., Panella B.: State-of-Art and selection of techniques in multiphase flow measurement. Report RdS/2010/67, Torino 2010 .

[5] Falcone G., Hewitt G., Alimonti C.: Multiphase Flow Metering: Principles and Applications (Developments in Petroleum Science 54). Elsevier Science, 2009.

[6] Fang L., Zhang T., Jin N.: A comparison of correlations used for Venturi wet gas metering in oil and gas industry. Journal of Petroleum Science and Engineering 57, 2007, 247-256

[7] Geng Y., Zheng J., Shi T.: Study on the metering characteristics of a slotted orifice for wet gas flow. Flow Measurement and Instrumentation 17, 2006, $123-128$.

[8] Hua C., Geng Y.: Wet gas metering technique based on slotted orifice and swirlmeter. Flow Measurement and Instrumentation 30, 2013, 138-143.

[9] Huang S., Ma T., Wang D., Lin Z.: Study on discharge coefficient of perforated orifices as a new kind of flowmeter. Experimental Thermal and Fluid Science 46, 2013, 74-83.

[10] ISO/TR 15377:2007: Measurement of fluid flow by means of pressuredifferential devices- Guidelines for the specification od orifice plates, nozzles and Venturi tubes beyond the scope of ISO 5167, 2007.

[11] Morrison G. L., Hall K. R., Holste J. C., DeOtte R. E., Macek M. L., Ihfe L. M. Slotted Orifice Flowmeter. AIChE Journal 40(10), 1994, 1757-1760.

[12] Morrison G. L., Hall K. R., Holste J. C., Macek M. L., Ihfe L. M., De Otte R. E., Terracina D.: Comparison of orifice and slotted plate flowmeters. Flow measurement and Instrumentation 5(2), 1994, 71-77.

[13] Morrison G. L., Terracina D., Brewer C., Hall K.R.: Response of a slotted orifice flow meter to an air/water mixture. Flow Measurement and Instrumentation 12, 2001, 175-180.

[14] Steven R., Hall A.: Orifice plate meter wet gas flow performance. Flow Measurement and Instrumentation 20, 2009, 141-151.

\begin{abstract}
M.Sc. Eng. Barbara Tomaszewska-Wach
e-mail: b.tomaszewska@po.edu.pl

Assistant in the Department of Thermal Technology and Industrial Equipment at the Faculty of Mechanical Engineering of the Opole University of Technology. In scientific work I deal with research on the flow of single-phase and two-phase fluid through orifices of various geometric shapes. Areas of interest are issues related to experimental and numerical fluid mechanics.
\end{abstract}

ORCID ID: 0000-0002-9796-1013

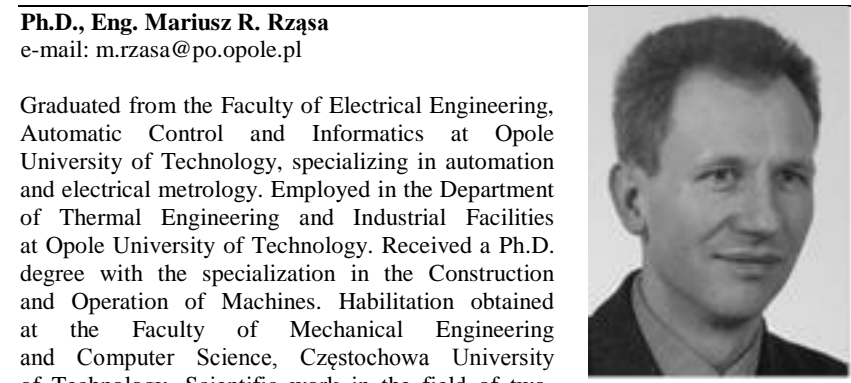
of Technology. Scientific work in the field of twophase flow measurement

ORCID ID: 0000-0002-3461-2131

\section{M.Sc. Eng. Marcin Majer \\ e-mail:m.majer@po.edu.pl \\ Faculty of Electrical Engineering, Automatic Contro and InformaticInstitute of Computer Science Scientific interests focused around broadly defined computer science and automation related to algorithmics, parallel programming, optimization, and the use of computer clusters.}

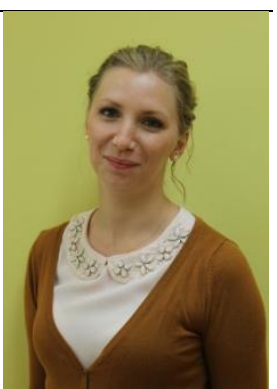

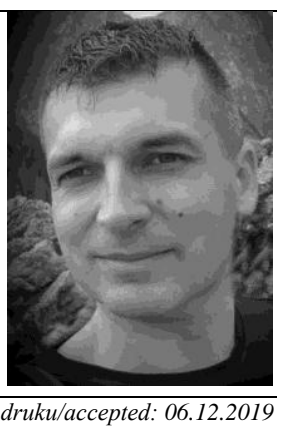

